Brit. J. vener. Dis. (1961), 37, 252.

\title{
SERUM LEVELS OF PENICILLIN AND THEIR VARIATIONS AFTER ADMINISTRATION OF BENZATHINE PENICILLIN IN CHILDREN*
}

\author{
BY \\ J. PELlERAT, M. A. MAILlARD, AND R. CARRON \\ Paris
}

During a study of the serum levels of penicillin necessary for the prophylaxis of rheumatic fever in children (Carron, Maillard, and Pellerat, 1961) we made some observations which could have practical importance in the treatment of syphilis. We observed certain variations in the serum levels after the administration of benzathine penicillin some of which appeared to be rather paradoxical. In general, our results showed satisfactory levels after benzathine penicillin and confirm the remarkable delayed effect of the preparation already reported by Szabo, Edwards, and Bruce (1951), Elias, Price, and Merrion (1951), Stollerman and Rusoff (1952), Mann, Rein, Bunn, Flax, and Morseburg (1953), Fletcher and Knappett (1953), Welch, Randall, and Hendricks (1953), Putnam and Roberts (1954), Nelson, Talbot, and Binns (1954), Mozziconacci, Gerbeaux, and Dupuy-Joie (1957), Wright, Welch, Wilner, and Roberts (1959).

As penicillin has a treponemicidal action at levels between 0.004 and 0.010 unit (Eagle, Fleischman, and Musselman, 1950; Durel, Sausse, Collart, Roiron, and Borel, 1951; Durel and Borel, 1958), the time during which the serum level is sufficiently

* Paper read at the M.S.S.V.D. meeting in Paris on May 12, 1961. raised to assume 100 per cent. protection against treponemal infection can be assessed.

We have studied the serum penicillin levels in 131 children aged 5 to 15 years after the following intramuscular injections:

(1) 600,000 units benzathine penicillin (B.P.).

(2) 600,000 units B.P. plus 300,000 units penicillin G plus 300,000 units procaine penicillin $G$.

(3) $1,200,000$ units B.P.

(4) $1,200,000$ units B.P. as two simultaneous intramuscular injections of 600,000 units each.

\section{Technique and Results}

The serum penicillin levels were estimated by the classical technique of diffusion in agar at $\mathrm{pH} 6.5$ seeded with sarcina lutea. The $\mathrm{pH}$ plays an important part in the diffusion, each serum being buffered by diluting it with a phosphate buffer at pH 6. The standard range is prepared in human serum also buffered by half dilution with buffer at pH 6. The test is read after incubation at $30^{\circ} \mathrm{C}$. for $20 \mathrm{hrs}$. The maximum range is about 15 milliunits.

I. Serum Penicillin Levels obtained after one INTRAMUSCUL AR INJECTION OF 600,000 UNITS B.P.-The high serum levels between the 14th and 18th day show that protection from treponemal infection is 100 per cent. (Table I).

TABLE I

600,000 UNITS BENZATHINE PENICILLIN IN ONE INJECTION

\begin{tabular}{|c|c|c|c|c|c|c|}
\hline \multirow{2}{*}{ Time after Injection } & \multirow{2}{*}{$\underset{\text { (yrs) }}{\text { Average Age }}$} & \multirow{2}{*}{$\begin{array}{c}\text { Average Weight } \\
\text { (kg.) }\end{array}$} & \multirow{2}{*}{$\begin{array}{c}\text { Number of } \\
\text { Laboratory } \\
\text { Investigations }\end{array}$} & \multicolumn{3}{|c|}{ Milliunits Penicillin per $\mathrm{ml}$. Serum } \\
\hline & & & & Extremes & Median & Average \\
\hline $3 \mathrm{hrs}$ & 10 & $31 \cdot 2$ & 15 & 100 to 800 & 380 & 392 \\
\hline $6 \mathrm{hrs}$ & 10 & $31 \cdot 2$ & 15 & 64 to 640 & 200 & 297 \\
\hline $12 \mathrm{hrs}$ & 11 & $39 \cdot 8$ & 9 & 90 to 330 & 200 & 200 \\
\hline $24 \mathrm{hrs}$ & 10 & $37 \cdot 9$ & 11 & 80 to 315 & 208 & 203 \\
\hline 3-8 days & $11 \frac{1}{2}$ & $35 \cdot 8$ & 37 & 0 to 360 & 43 & 74 \\
\hline 9-13 days & 11 & $38 \cdot 7$ & 12 & 0 to 388 & $41 \cdot 5$ & 44 \\
\hline 14-18 days & $10 \frac{1}{2}$ & $33 \cdot 0$ & 27 & 0 to 225 & 25 & 39 \\
\hline 19-21 days & $10 \frac{1}{2}$ & $32 \cdot 5$ & 20 & 0 to 154 & 0 & $18 \cdot 5$ \\
\hline
\end{tabular}


II. Serum Penicillin Levels obtained after Injection of a Preparation containing 600,000 units B.P., Plus 300,000 units Penicillin G, Plus 300,000 units ProCAINe Penicillin G.-These $1,200,000$ units of combined penicillins have the same effect as 600,000 units of longacting penicillin (Table II). Although the serum penicillin levels are higher for the first $6 \mathrm{hrs}$, they later become identical with those found after 600,000 units B.P. Here again, protection against treponemal infection is 100 per cent. between the 14th and 18th day.

III. Serum Penicillin Levels obtained after InjecTION OF $1,200,000$ UNITS B.P. - We observed levels of about 200 milliunits during the first $24 \mathrm{hrs}$, similar to those seen after an injection of 600,000 units B.P., but the levels on the following days were much higher than with 600,000 units, and on the 28th day the levels were still much higher than those required to ensure 100 per cent. protection (Table III).

IV. Serum Penicillin Levels aftfr the AdministraTION OF $1,200,000$ units B.P. IN Two Simultaneous INTRAMUSCULAR INJECTIONS OF 600,000 UNITS EACH.The injection of a single dose of $1,200,000$ units B.P. in a baby with small muscles often causes a painful local reaction. As 600,000 units B.P. is usually well tolerated, we hoped that giving $1,200,000$ units as 600,000 units into each buttock would prevent the painful reaction and also maintain the same high serum level. Table IV (overleaf) shows that the technique gives total protection 28 days after the double injection but, surprisingly, the levels obtained after 8 days, 14 days, 21 days, and 28 days were notably less than those obtained after the single injection of $1,200,000$ units B.P.

\section{Observations}

Certain observations made during our investigations are worthy of emphasis.

(1) Abnormally High, Levels. - At first these were thought to be due to errors of dosage or to the use of contaminated syringes, but we were able to eliminate all possible causes of error due to the apparatus, and to show by the use of penicillinase that the serum contained only penicillin.

(a) 14 days after 1,200,000 units pure B.P.-Four children were observed to have extraordinary levels.

TABLE II

1,200,000 UNITS BENZATHINE PENICILLIN, AND BIPENICILLIN

\begin{tabular}{|c|c|c|c|c|c|c|}
\hline \multirow{2}{*}{ Time after Injection } & \multirow{2}{*}{$\underset{\text { (yrs) }}{\text { Average Age }}$} & \multirow{2}{*}{$\underset{\text { (kg.) }}{\text { Average Weight }}$} & \multirow{2}{*}{$\begin{array}{c}\text { Number of } \\
\text { Laboratory } \\
\text { Investigations }\end{array}$} & \multicolumn{3}{|c|}{ Milliunits Penicillin per $\mathrm{ml}$. Serum } \\
\hline & & & & Extremes & Median & Average \\
\hline $3 \mathrm{hrs}$ & 10 & $33 \cdot 6$ & 24 & 800 to 4,900 & 1,875 & 2,176 \\
\hline $6 \mathrm{hrs}$ & 10 & $33 \cdot 6$ & 24 & 175 to 3,900 & 600 & 921 \\
\hline $12 \mathrm{hrs}$ & 81 & $27 \cdot 0$ & 9 & 208 to 440 & 272 & 295 \\
\hline $24 \mathrm{hrs}$ & 8 & $25 \cdot 8$ & 13 & 170 to 425 & 260 & 277 \\
\hline $3-8$ days & 11 & $38 \cdot 0$ & 48 & 0 to 470 & $56 \cdot 5$ & 86 \\
\hline $9-13$ days & 11 & $36 \cdot 0$ & 33 & 0 to $\quad 400$ & 60 & 75 \\
\hline $14-18$ days & 11 & $35 \cdot 0$ & 35 & 0 to 320 & 30 & 39 \\
\hline $19-21$ days & 111 & $34 \cdot 0$ & 19 & 0 to $\quad 88$ & 0 & 24 \\
\hline
\end{tabular}

TABLE III

$1,200,000$ UNITS PURE BENZATHINE PENICILLIN IN ONE INJECTION

\begin{tabular}{|c|c|c|c|c|c|c|}
\hline \multirow{2}{*}{ Time after Injection } & \multirow{2}{*}{$\underset{(y r s)}{\text { Average Age }}$} & \multirow{2}{*}{$\underset{(\mathrm{kg} .)}{\text { Average Weight }}$} & \multirow{2}{*}{$\begin{array}{c}\text { Number of } \\
\text { Laboratory } \\
\text { Investigations }\end{array}$} & \multicolumn{3}{|c|}{ Milliunits Penicillin per $\mathrm{ml}$. Serum } \\
\hline & & & & Extremes & Median & Average \\
\hline 3 hrs & $10 \frac{1}{2}$ & 36 & 17 & 100 to 490 & 225 & 246 \\
\hline $6 \mathrm{hrs}$ & $10 \frac{1}{2}$ & 36 & 17 & 80 to 420 & 170 & 192 \\
\hline $24 \mathrm{hrs}$ & $10 \frac{1}{2}$ & 36 & 17 & 100 to 535 & 245 & 253 \\
\hline 8 days & $10 \frac{1}{2}$ & 36 & 39 & 25 to 119 & 57 & 61 \\
\hline 14 days & $10 \frac{1}{2}$ & 36 & 33 & 24 to 184 & 50 & 67 \\
\hline 21 days & 11 & 36 & 20 & 19 to 132 & 42 & 61 \\
\hline 28 days & 91 & 28 & 11 & 0 to 58 & 29 & 24 \\
\hline
\end{tabular}


TABLE IV

1,200,000 _UNITS BENZATHINE PENICILLIN (600,000 UNITS INTO EACH BUTTOCK)

\begin{tabular}{|c|c|c|c|c|c|c|}
\hline \multirow{2}{*}{ Time after Injection (days) } & \multirow{2}{*}{$\underset{(y r s)}{\text { Average Age }}$} & \multirow{2}{*}{$\begin{array}{c}\text { Average Weight } \\
\text { (kg.) }\end{array}$} & \multirow{2}{*}{$\begin{array}{l}\text { Number of } \\
\text { Laboratory } \\
\text { Investigations }\end{array}$} & \multicolumn{3}{|c|}{ Milliunits Penicillin per ml. Serum } \\
\hline & & & & Extremes & Median & Average \\
\hline 8 & 11 & 38 & 21 & 20 to 140 & $47 \cdot 5$ & 53 \\
\hline 14 & 11 & 38 & 20 & 0 to 80 & 31 & 31 \\
\hline 21 & 11 & 38 & 20 & 0 to 100 & 11 & 24 \\
\hline 28 & 11 & 38 & 13 & 0 to 50 & 13 & 15 \\
\hline
\end{tabular}

Case 1: The level remained between 200 milliunits at the 3rd hour and 76 milliunits on the 8th day, and showed 17,000 milliunits on the 14 th day.

Case 2: The level remained between 200 milliunits at the 3rd hour and 36 milliunits on the 8 th day, and showed 1,400 milliunits on the 14 th day.

Case 3: The level was between 350 and 50 milliunits under similar conditions, and showed 38,000 milliunits on the 14 th day.

Case 4: The levels oscillated between 135 and 56 milliunits, and showed 1,400 milliunits on the 14th day.

(b) 8 days after 600,000 units B.P. plus 300,000 units penicillin $G$, plus 300,000 units procaine penicillin G.-Two children showed a rapid rise in these circumstances although their levels before the 8 th day were normal.

Case 5: The level rose to 9,000 milliunits.

Case 6: The level rose to 24,000 milliunits.

(c) 8 days after 600,000 units B.P.-Case 7 suddenly showed a level of 2,400 milliunits.

(d) Some children showed serum levels which were less extraordinary, but were abnormally raised on the 14 th, 21 st, or 28th day after the injection.

28 days after 1,200,000 units B.P.: Case 8 showed a level of 600 milliunits although he had levels in the neighbourhood of 40 milliunits on the 8th, 14th, and 21 st days after the injection.

21 days after 1,200,000 units B.P.: Cases 9 and 10 had levels in the neighbourhood of $\mathbf{4 5 0}$ milliunits, compared with 35 to 40 milliunits on the 8th and 14th days after the injection.

14 days after 1,200,000 units B.P.: Cases 11 and 12 had levels of $\mathbf{4 3 0}$ and $\mathbf{3 4 0}$ milliunits compared with $\mathbf{5 0}$ milliunits on the 8th day after injection.

28 days after 1,200,000 units B.P. in two separate injections: Case 13 had a level of 206 milliunits after showing 40,50 and 28 on the 8 th, 14th, and 21 st days after the injection.

14 days after 600,000 units B.P.: Case 14 had a level of 225 milliunits after showing 80 to 31 milliunits at $24 \mathrm{hrs}$ and 8 days after the injection.

21 days after 600,000 units B.P.: Cases 15 and 16 had levels of 154 and 180 milliunits after showing 30 milliunits 8 days after the injection and 26 and 66 milliunits 14 days after the injection.

(2) Irregular Levels. - These were described by Fletcher and Knappett (1953) and we have also found these paradoxical results. Several children were tested on different occasions and the serum penicillin levels at corresponding times were found to differ from one examination to another.

Case 17 was tested twice after 600,000 units B.P. and 600,000 units Bipenicillin, and showed the following levels:

\begin{tabular}{c|r|r}
\hline Time after Injection & 1st Test & 2nd Test \\
\hline At 3 hrs & 1,050 & 2,000 \\
At 6 hrs & 275 & 3,900 \\
At 8 days & 78 & 34 \\
At 14 days & 68 & 0 \\
\hline
\end{tabular}

Case 6 was tested three times after 600,000 units B.P. and 600,000 units Bipenicillin, and showed the following levels:

\begin{tabular}{c|r|r|c}
\hline $\begin{array}{c}\text { Time after } \\
\text { Injection }\end{array}$ & 1st Test & 2nd Test & 3rd Test \\
\hline At 3 hrs & 1,500 & 3,500 & - \\
At 6 hrs & 450 & 880 & - \\
*At 8 days & 24,000 & 470 & 76 \\
At 14 days & 0 & 0 & 350 \\
\hline
\end{tabular}


Case 5 was tested twice after 600,000 units B.P. and 600,000 units Bipenicillin. The serum level after 8 days was 9,000 milliunits at the first test and 39 milliunits at the second.

The reason for these variations is unknown, but they may perhaps be due to irregular absorption. Stollerman and Rusoff (1952) eliminated the factor of muscular activity by studying two groups of convalescent children, one group confined to bed and the other having normal physical activity. In both groups, the same unexpected irregularities were observed.

(3) Late Effective Levels. - In a few cases a negative penicillin serum level became positive the following week.

Case 18: After 600,000 units B.P., the level was 0 after 8 days and 46 at 21 days.

Case 19: After 600,000 units B.P., the level was 0 after 8 days, 27 at 14 days, and 29 at 21 days.

Case 20: After 1,200,000 units B.P. (Bipenicillin), the level was 0 after 8 days, 82 at 14 days, and 0 at 21 days.

(4) Levels remaining at Zero beyond the 8th Day.Cases 21 and 22 after 600,000 units and Case 23 after $1,200,000$ units B.P. had zero levels at 8,14 , and 21 days.

\section{Discussion}

These results confirm the findings in the literature and demonstrate that an assured serum penicillin level is usually produced by B.P. The different results obtained from the injection of $1,200,000$ units B.P. and from two simultaneous injections of 600,000 units B.P. are interesting. The amount of the dose in a given volume injected into a single muscle mass determines the absorption of the product and it is clear that the absorption is slower when the volume and the dose are high.

Irregularities in the levels observed some time after the injection have already been noted by different authors, and are difficult to explain. It has been thought that muscular activity may condition absorption, but the study of Stollerman and Rusoff (1952) refutes this hypothesis. We also have been unable to establish a relationship between physical activity in children and serum penicillin levels. Moreover, in children tested under similar conditions we have found variable levels from one examination to another. There are levels which rise abruptly as though the whole mass of penicillin was absorbed rapidly; conversely, the levels may remain at zero for some time as though the injected penicillin was encysted and rendered inert in the muscle or had been prematurely eliminated in the urine. Although these anomalies are infrequent in relation to the total number of children studied and to the number of injections given, they remain a source of disquiet.

\section{Summary}

In children from 5 to 15 years of age benzathine penicillin enables treponemicidal levels to be maintained in the serum for periods varying with the dose administered: 14 to 18 days after 600,000 units, 28 days at least with $1,200,000$ units.

Preparations consisting of 600,000 units B.P., 300,000 units penicillin $G$, and 300,000 units procaine penicillin $G$ gave delayed levels which were identical with those obtained with 600,000 units B.P.

In some cases unexpected variations were observed after injections of different amounts. The abnormally high or irregular levels sometimes encountered suggest that the penicillin depot in muscle may be suddenly liberated in circumstances which cannot be determined clinically. On the other hand, zero levels may also occur at different times which cannot be explained by muscular conditions.

\section{REFERENCES}

Carron, R., Maillard, M. A., and Pellerat, J. (1961). Pédiatrie, 46, 153.

Durel, P., and Borel, L. J. (1958). Presse méd., 66, 1827. Sausse, A., Collart, P., Roiron, V., and Borel, L. J. (1951). Proph. antivénér., 23, 59.

Eagle, H., Fleischman, R., and Musselman, A. D. (1950). J. Bact., 59, 625.

Elias, W., Price, A. H., and Merrion, H. J. (1951). Antibiot. and Chemother., 1, 491.

Fletcher, A. P., and Knappett, C. R. (1953). Brit. med. J., $1,188$.

Mann, C. H., Rein, C. R., Bunn, P. A., Flax, S., and Morseburg, C. (1953). "Antibiotics Annual, 1953$54 "$, p. 346.

Mozziconacci, P., Gerbeaux, C., and Dupuy-Joie, Y. (1957). Sem. Hôp. Paris, 33, 2160.

Nelson, M. G., Talbot, J. M., and Binns, T. B. (1954). Brit. med. J., 2, 339.

Putnam, L. E., and Roberts, E. F. (1954). Antibiot. and Chemother., 4, 931.

Stollerman, G. H., and Rusoff, J. H. (1952). J. Amer. med. Ass., 150, 1571.

Szabo, J. L., Edwards, C. D., and Bruce, W. F. (1951). Antibiot. and Chemother., 1, 499.

Welch, H., Randall, W. A., and Hendricks, F. D. (1953). Ibid., 3, 1053.

Wright, W. W., Welch, H., Wilner, J., and Roberts, E. F. (1959). Antibiot. Med., 6, 232.

Taux sanguins de pénicilline et leurs variations après benzathine pénicilline (B.P.) chez l'enfant

\section{RÉSUMÉ}

Chez l'enfant de 5 à 15 ans la benzathine pénicilline permet d'obtenir des taux sanguins tréponémicides dont 
la durée varie selon la dose administrée; 14 à 18 jours après 600.000 unités, 28 jours au moins après 1.200 .000 unités.

La préparation comportant 600.000 unités de B.P. $300.000 \mathrm{u}$. de pénicilline $\mathrm{G}$, et $300,000 \mathrm{u}$. de procaïne pénicilline $G$ donne des taux sanguins tardifs identiques à ceux obtenus avec 600.000 unités de B.P.

Deux injections simultanées de 600.000 unités de B.P. assurent une protection de 28 jours, mais donnent des taux sanguins nettement inférieurs à ceux obtenus avec une seule injection de 1.200 .000 unités de B.P.

Chez un certain nombre de sujets des variations assez paradoxales ont pu être observées après l'injection des différentes doses; taux anormalement élevés et taux irréguliers qui laisseraient à penser que la Pénicilline en dépot dans le muscle est brusquement libérée dans des conditions qui ne peuvent être cliniquement déterminées, ou au contraire taux nuls à différentes reprises qu'aucune anomalie musculaire ne peut expliquer. 